\title{
Unnatural River, Unnatural Floods? Regulation and Responsibility on the Murray River in the 1950 s $^{1}$
}

\author{
EMILY O'GORMAN
}

'I have read the reports in your newspaper of the recent flooding', wrote Geoff L. Harrison, Executive Engineer of the River Murray Commission (RMC), to the Border Morning Mail in 1958 ('Flood Control' pt. 2). '[A]nd', he continued, 'because of reported inaccurate statements regarding this flood and some misconceptions regarding floods generally, I feel that the following facts should be placed on record'. Harrison was responding to claims by farmers that the Hume Dam, operated by the Commission, had caused recent floods on the Murray River. He denied that water releases had exacerbated floods for those below the dam: 'statements that the gates were raised, allowing large volumes of water to escape, or that it was a "man-made" flood, are inaccurate as no stored water was released'. He argued that floods had occurred 'from time immemorial', and that when river flow was 'too large to be contained in the channel it spreads over its own floodplain'. He criticised negative press reports that 'abuse the river (or some convenient authority) for the destruction it has wrought' ('Flood Control' pt. 2). Harrison's position was that floods were 'natural' occurrences, dams and officials should not be blamed; but they were.

Harrison's strong defence of dams highlights significant changes in people's understandings about the river in flood with and without dams. The Murray River, like many rivers in Australia, has flooded (and dried up) intermittently since well before European settlement. The evolution of complex floodplain ecologies along the river attests to this. In the period since colonisation, those living along the river had experienced a number of large floods, for example in 1870, 1917 and 1927. However, the building of large dams and other regulatory structures brought changes to both the environment and understandings of floods and the river. What does it mean that floods could be seen as 'man-made'? What does this tell us about changing understandings of the Murray at a time when its flows were rapidly being regulated through large dams and other structures?

1 This paper uses the measurements, monetary values and currency quoted in primary sources, except where conversions to contemporary units and values have been necessary for comparison or clarity. 
Blaming the government for floods was a cultural and political shift induced by the timing and size of the 1956 floods, which occurred two years before Harrison wrote his letter. These floods remain the only time the Murray and Darling river systems have flooded together since European colonisation. The event occurred after four decades of transforming the Murray into a regulated river, a period of world history in which dams became powerful symbols of the transformative power of engineering and technology. Yet it appeared engineering had not delivered the promised environmental security. It seemed to some that dams, built to minimise the effects of drought, were paradoxically bringing floods. More, albeit smaller, floods in 1958 increased farmers' concerns over the operation of dams and indeed the very presence of these large regulatory structures in the upper Murray and its tributaries.

The Murray is one of the longest rivers in Australia, second only to the Darling, which is one of its tributaries. ${ }^{2}$ Together, these river systems form what is now known as the Murray-Darling Basin, which covers approximately one seventh of Australia (Australian Bureau of Statistics, 'Water'). The Murray's headwaters are in the Great Dividing Range, a mountain range that runs along the east coast of Australia. The river is fed by many tributaries that are filled by snowmelt from these ranges as well as rainfall. The Murray forms most of the length of the state boundary between New South Wales and Victoria, and also runs through South Australia before emptying into the Indian Ocean. The river is highly significant; it forms the cornerstone of Australia's agricultural industry, is an important site of biodiversity, and is deeply embedded in both Indigenous and non-Indigenous cultures (Weir 26-46; Sinclair 3-25). In the midst of Australia's current period of growing water uncertainty, especially along the Murray, it is important that we revisit pivotal moments such as the 1956 and 1958 floods and the building of large dams which have shaped the physical and cultural landscape in such an enduring way.

This paper focuses on the 1956 and 1958 floods in the Murray as turning points in understandings of floods, the river and dams. Analysis centres on a set of newspaper clippings, as well as other documents, from two archives held by the National Archives of Australia. These archives are two halves of a bigger file, titled 'Flood Control - investigation of flood control and mitigation in the Murray Valley' ('Flood Control' pt. 1 and pt. 2). The records are from the office of the Commonwealth Minister for National Development, William Henry Spooner, and focus in large part on responses by the federal government to the 1956 and, to a lesser extent, 1958 floods. This department, which was created in 1950 and dissolved in 1972, was at the forefront of river regulation and the

2 The Darling River system, however, has a very different hydrology from the Murray River system and they are somewhat independent. The Darling River system is affected by northern monsoonal rains, whereas the flow in the Murray is largely dependent on winter rainfall and spring snowmelt (see Pittock et al.). 
'planning and co-ordination' of other projects towards 'the development of natural resources on a national basis' (Department of National Development). It oversaw federal interests in the construction of the Snowy Mountains HydroElectric Scheme. In addition, Spooner headed the state/federal conglomeration that was the RMC, the precursor to the Murray-Darling Basin Initiative and the then facilitator of cost-shared engineering works as well as river research (Department of National Development; Merritt 62).

The newspaper clippings I have selected from this file centre on the increasing concerns of farmers about the effects of the Snowy Mountains Scheme and the Hume Dam on floods. In particular, I concentrate on newspaper articles from the Border Morning Mail, published in the town of Albury, then the centre of a dairy region and located along the upper Murray River in New South Wales, just below the Hume Dam. This region also encompasses the town of Wodonga, on the opposite bank of the Murray in Victoria. Through these articles we can glimpse bigger transitions in the way rivers and floods were understood after the construction of dams and some of the significance of these years of rapid change.

I focus on three issues that bring together and explore experiences of environmental, cultural, and technological transformation. First, I examine what greater government involvement in river flow and centralised control through large-scale dams has meant for changes in environmental understandings, particularly understandings of floods as 'natural' events. Second, there is an undercurrent of anxiety in newspaper editorials by farmers that dams had, and would continue to, change the way floods flowed across farming land, including their size and frequency. Following the 1956 and 1958 floods people were concerned that the dams could alter flood flow so drastically that previous knowledge and experience did not prepare them for these radically different flows. Dams became sources of uncertainty about future environmental, and related economic, change.

Last, I explore anxieties and disputes around dams and the floods within a political context. Non-irrigators expressed a sense of injustice towards government policies and river regulation that favoured the interests and expansion of the irrigation industries and small-scale farming, such as fruit, vegetable, and nut farming, small-scale dairies, and viticulture. Largely nonirrigating primary producers, like cattle and sheep graziers and some dairy farmers, were increasingly being sidelined in government policies and projects. ${ }^{3}$

3 There was both irrigated and non-irrigated dairy farming. Small-scale irrigated diary farming was being encouraged at this time (and later) by state programs of closer settlement (see footnote 6). Dairy farmers increasingly employed irrigation techniques. For example, between 1979 and 1982, 79.4 percent of the total area under irrigation in Victoria was used for pasture (Powell, Watering 255). 
They questioned technocratic projects of national development and the bias of governments at a time of widespread support for the regulation of the Murray for irrigation water supply.

The 1956 and 1958 floods and their fallouts must be seen within the wider context of inter-war and post-war development (1930s to 1960s) and the 1950s as a decade of change in Australia. As Nicholas Brown has argued in Governing Prosperity, 'the 1950s bear a particular weight as a point of separation between an old and a new Australia'; from 'an Australia of class, hardship, Empire and assertive nationalism' to 'the cultural diversity, the "quality of life" issues, the protest movements and the liberations of the 1960s' (2). This paper adds to Brown's critique of the common view of the 1950s as a period in Australian history that was conservative and static and supports his argument that it was rather a decade of transition. In order to demonstrate more fully the significance of these floods, then, I will draw attention to the wider context in which they occurred and begin with a short discussion of the regulation of the Murray and the ideas that underpinned the radical transformation of an entire river system.

\section{Regulating the Murray River}

In the 1950s, people living along the Murray were experiencing one of the most dramatic environmental interventions in twentieth-century Australia, the regulation of the Murray simultaneously for drought mitigation, navigation, irrigation and hydro-electricity. Dam-building was part of an almost worldwide post-war pursuit of progressionist development that provided employment for the unemployed and immigrants, new production bases, and symbols of nationalism. It was underwritten by a renewed faith in human ability and technology. Jacques Leslie, reflecting on the impact of dams in 2005, noted that large dams can today be found in '60 percent of the world's two hundred-plus major river basins' and geophysicists speculate that the shift in weight from these storages has 'slightly altered the speed of the earth's rotation, the tilt of its axis, and the shape of its gravitational field' (4). Constructions built in the postwar period were major contributors to this planetary change; they also heralded more local and rapid spatial, social, and political transformations.

The Murray was transformed into a 'regulated river' in just one generation, through state-, interstate-, and federally-built dams. The Lake Victoria Reservoir, Hume Dam, Snowy Mountains Hydro-Electric Scheme, five barrages on Lake Alexandrina blocking the Murray mouth, thirteen locks spanning the Murray, 
Lake Mulwala and other works were completed between 1915 and 1974, and all were at least under construction by $1956 .{ }^{4}$ Most of these structures were the result of a concerted and shared effort to 'canalise' the river, a policy agreed upon by the members of the RMC after its establishment in 1917. The RMC included representatives of the three states that shared the Murray (New South Wales, Victoria, and South Australia) and the Commonwealth government. The canalisation of the Murray aimed to make it into a channel to support water supply from dams to irrigation settlements and, initially, to improve river navigation. The expansion of irrigation soon became the dominant rationale for the regulation of the Murray. In effect, this was an attempt to create a new, controllable river (Lloyd 181-84; Wright 281-83; Connell 56-61).

The dams were built by governments, the largest through joint interstate and federal organisations like the RMC and Snowy Mountains Hydro-Electric Authority (SMA). ${ }^{5}$ One of the primary interests of these organisations and the role of the dams was to ensure security to government-backed soldier and 'closer' settlements on the Murray, which were mainly irrigation communities. ${ }^{6}$ The dams would control river flow, ensuring there was water in the river at the right times for citrus and vine cultivation and minimise the effects of drought.

These watershed management systems heralded a new kind of relationship between people and the rivers. The seasonal flows of the Murray River were reversed for irrigation needs and eastward flowing rivers turned westward by the Snowy Mountains Scheme. The fearless ideologies of control and management that underlay river engineering were given expression in the construction of dams and irrigation planning and farming. Such ideologies were rooted in ideas of holistic, watershed manipulation. It was an era when largescale enterprises - 'bigness' - commanded national and international respect, both in the size of dams and control over entire river systems. Big achievements promised 'great rewards' (Casey v). Irrigation settlements had been established along the Murray since the 1880s, but the Hume Dam and Snowy Mountains Scheme were built to feed irrigation networks on an unprecedented scale.

\footnotetext{
4 A 'barrage' is a structure built across a watercourse to regulate and manage water flow. The barrages built near the mouth of the Murray were intended to control upstream water levels for irrigation, reduce salinity levels along the lower Murray, improve navigation at the Murray's mouth and reserve pool water for Adelaide and southeastern South Australia (Murray-Darling Basin Commission, 'The Barrages').

5 The state governments involved in dam-building on the Murray and in interstate/federal organisations were the three that laid claim to part of that river: Victoria, New South Wales and South Australia.

6 'Closer settlement' was the settlement of people on the land by the government at a high density, usually with the aim of increasing faming production through defined and limited farming plots within defined areas of settlement. Returned servicemen were some of those 'settled' on irrigation blocks (see Lloyd 184-185; Powell, Watering 146-47, 150, 167-70).
} 


\section{Dams and national development: the Hume Dam and the Snowy Mountains Scheme}

Since the 1930s the Hume Dam has been the primary regulatory structure for irrigation releases along the Murray. Initiated in 1919 and completed in 1936, the Hume was built as a joint venture between the Victorian and New South Wales governments, and was operated by the RMC. The Hume was widely revered as a technological achievement and as representative of a new human ability to control the river. Built in the inter-war period, the dam was intended to support existing irrigation farming and to create the opportunity for state governments to expand agricultural production on an unprecedented scale (Sinclair 69-71). ${ }^{7}$

The Hume was intended to alter the Murray's flows radically, and it did. Historian Paul Sinclair has noted that by 1939, only three years after the dam began operation, 'the Murray's flow had been substantially modified from its natural condition by the operation of the Hume Dam' (69). The Murray changed from being 'generally high, cool, turbid, and fast-flowing in spring and early summer' to being 'low, warm, slow flowing and clear by the end of summer' (69). The dam held back water that covered an area of 33,000 acres and enabled dramatic increases in the area of land under irrigation in Victoria and New South Wales: from 814,000 acres in 1939 to 1,406,000 acres in 1946 (Sinclair 73). The Hume remains the 'work horse' of irrigation along the length of the Murray.

Together with the massive casualties of the Second World War came exponential leaps in technology, progressionist ideologies of control and concerns for national security. It was within this context that the Snowy Mountains Scheme was initiated. The Scheme, which began construction in 1949 and was completed in 1974, was envisaged as an engineering masterpiece of post-war reconstruction: an intricate system of dams to feed the Murray and Murrumbidgee irrigation industries and harness the regular seasonal snowmelt for hydro-electricity. Historian George Seddon has drawn attention to an important underlying motive for the massive engineering scheme: the belief that use of water resources on the dry continent needed to be maximised (Seddon 36-37; see also Powell, Watering 248-49). Post-war Australia aimed at national security, including food production, and the Snowy was an integral part of this plan as, together with the Hume and other structures, it would create a stable river for agricultural farming (Powell, Watering 207, 224-25). Whilst a product of post-war anxiety, it was also part of the 1950s self-conscious drive towards modernity, following the examples of America's massive water diversion and hydro-electric projects, such as the Hoover Dam, dams along the Mississippi River, and the Tennessee Valley weirs (Tyrrell 173; Powell, Watering 204-05; Powell, Emergence 48-51;

7 For more on the Hume Dam and the role of the RMC see Eaton 46-47. 
Wigmore 122). ${ }^{8}$ It was conceived within, and regenerated, a national mood of faith in techno-culture. The Scheme became a powerful symbol of Australia's development and modernisation within a global drive towards technical advancement rooted in national and progressionist projects. ${ }^{9}$

The project was the largest engineering scheme yet undertaken in Australia and was vested with national pride. Sir William Hudson, Commissioner of the SMA, articulated the importance of the scale of the project, which was 'teaching us ... to think in a big way ... to be proud of big enterprises' (quoted in Seddon 36). ${ }^{10}$ Seddon likened the impact of the Scheme to the Gallipoli myth in the rhetoric of heroism that surrounded it. It was also similar in the public unity and support and sense of national pride it generated (Seddon xxiii, 36). Environmental historian John Merritt recently recalled that in the 1950s '[v]irtually every Australian knew something about the dams and tunnels in the mountains that would boost the country's electricity supply and make the Riverina a vast food bowl - even, as the author can attest, school children in far off Western Australia' (59). The Scheme also attracted international attention for its 'complexity and size' (59). It was a symbol of post-war prosperity and is still referred to as 'the greatest engineering scheme in Australian history' (Australian Bureau of Statistics, 'The Snowy Mountains Hydro-Electric Scheme').

\section{The 1956 floods in an engineered landscape}

In an era of 'bigness', the 1956 floods conformed. In January 1956 the rivers and their tributaries were already high from heavy rainfall and flooding throughout the Darling and Murray watersheds in 1955, so that relatively little rain in 1956 could cause rivers to flood (Bond and Weisner). The earth was so saturated that rain did not soak in, but ran directly into swelling waterways and ravines. By February 1956 the McIntyre and Condamine catchments in Queensland were so waterlogged that the Bureau of Meteorology recorded a 100 percent runoff rate, causing increased flooding from relatively minor amounts of rain (25 to 100 millimetres) (Bureau of Meteorology; Brundt). On the Murray, especially near the point where the Darling was contributing its flood flows, the ground

\footnotetext{
8 Indeed, the Snowy Mountains Scheme's Commissioner, Sir William Hudson, recruited experienced hydroelectric engineers from America (Merritt 59-60). Ian Tyrrell has documented early Australian and American (especially Californian) exchanges of irrigation techniques, water management bureaucracy, knowledges and engineers. For further discussion on the probability that Australian water management influenced management in America, see Powell, Emergence 48-50; Powell, 'Australian Water' 61; O'Gorman 200.

9 For examples of dams and other technological projects in other countries that were connected with nationalism and state development in this period, see Leslie; Mitchell; Leybourne; Taylor; Worster; Reisner. 10 For further examples of the emphasis placed on the 'bigness' of the Snowy Mountains Scheme by its promoters see the Preface and Foreword to Lionel Wigmore's commissioned history of the Snowy Mountains Scheme written by the Right Honourable Lord Richard Gavin Gardiner Casey and Sir William Hudson respectively.
} 
was also saturated. In the irrigation district of Mildura, located on the Victorian side of the Murray River, the ground became so water-soaked in 1956 that the artesian aquifers rose to the surface. This made the ground so unstable that electricity pylons began to float. A resident later recalled that 'the ground was so saturated ... [that] in the switch yard you could push a 4 x 4 red gum straight into the ground over four foot just like that' (quoted in Chandler 16).

The hopes that dams would provide environmental security and a more consistent river were shattered by the floods. Water moved amorphously over the dams, submerging many irrigation areas. The Darling and Murray rivers and their tributaries all flooded in that year. Each waterway experienced localised floods and also, in most cases, a series of peaks. If the total area of the Murray and Darling systems is taken into account, floods were occurring from January until November, with the major peaks in the Murray in August and in the Darling in September. The floods were nebulous, spreading, peaking and pulsing through the watershed in irregular bursts and cumulative waves. Rainfall in April along both major rivers dramatically increased river heights, contributing to higher floods in August and September (Harrison; O'Gorman 215-33).

The amount of rain, length of its duration, and area it covered compounded to cause one of the most significant flood events since colonisation in what is now the Murray-Darling Basin. A later RMC report estimated that the floods in the Murray watershed alone covered approximately 1.75 million acres (as in the floods of 1870 and 1917) - it was amongst the largest floods along that river in terms of peak heights and submerged area (Harrison 12).

One year after the floods, the RMC assessed the total damage in the Murray and Darling watersheds to be $£ 5$ million (Harrison 23). Damage to private property, in New South Wales, Victoria and South Australia combined, was estimated to be $£ 1.5$ million, two thirds of which was in South Australia. The remaining portion of the estimate referred to damage to infrastructure and other government works and facilities. In 1997 Emergency Management Australia (EMA) produced a new cost estimate of the damages caused by the floods (EMA, '1956 Floods'). It estimated the floods between May and December 1956 to have cost $£ 30$ million (\$840 million, 1997 values) in New South Wales, Victoria and South Australia combined, increasing the initial assessment by $£ 25$ million. A large proportion of this overall cost was attributed to subsequent losses in agricultural production (EMA, '1956 Floods'). For example, the Australian Dried Fruits Association estimated in 1957 that 63 percent of the raisin crop, 22 percent of the currant crop and 27 percent of the sultana crop had been destroyed ('Severe Dried Fruit Losses').

Even in its failure, the new frame of engineering that scaffolded the river became the frame through which the floods were understood and reflected upon. None 
of the dams were constructed to mitigate floods, or included flood mitigation in their designs. Although the Murray River had flooded periodically, it was rather experiences of drought and the possibilities for irrigation (including increased population and production) that dominated popular and government desires for engineered works. Indeed, few dams in Australia then included any specific allowance for mitigating floods. The potential to use dams for this purpose had long been recognised by engineers in Australia and around the world, but mitigating floods through dams was costly and often any gain was thought to be outweighed by the expense of the structures. Flood mitigation more usually took other forms such as levee banks. ${ }^{11}$ After extensive and hugely damaging floods in parts of New South Wales and Queensland in February 1955, mitigation of floods though dams was initiated on a number coastal rivers in New South Wales. One of these rivers was the Hunter. On this river other means of flood mitigation that had been developed since the 1870s were overcome by the unprecedented 1955 floods. The floods caused extensive damage in this region, which had become a highly profitable farming area. Recuperation from the 1955 floods required significant state aid. The building of a flood mitigation dam now became justifiable in economic and humanitarian terms (Lloyd 288-89).

Following the 1956 floods, investigations into what was termed the 'flood problem' also began to receive greater attention along the Murray. Many people living along the river were concerned that flood mitigation now be addressed more thoroughly, either through dams or other means, such as building more levees. Some residents were also worried that the dams themselves could cause floods by redirecting water from one river into another. The Snowy Mountains Scheme, which had just come under construction, became an object of anxiety (Harrison 12).

\section{Doubting control: the 1956 floods}

One of the first indications of concern over the effect of dams on increasing flood heights came from a letter written by the leader of the Country Party in the Victorian Legislative Assembly, Thomas Francis Percy Byrnes. Byrnes wrote to Prime Minister Robert Menzies in the wake of the massive 1956 floods. He raised questions that had been put to his Party by people who lived along the upper Murray as well as 'further along the River'. People were 'disturbed at the possibilities of water being passed into the River from the Snowy Mountains Project at such times that floods would be augmented and damage done to adjoining lands' (Byrnes to Menzies, 9 November 1956, in 'Flood Control' pt. 1). ${ }^{12}$

11 Levees could, however, be problematic as they could raise flood heights in other places (see Lloyd 289).

12 Thomas Francis Percy Byrnes most often used his middle name 'Percy' as his first name, thus the letter in this file was attributed to 'P.T. Byrnes' (see Costar). 
The list of questions Byrnes included, based on those of residents, were probing and technical, focusing on the effects of water releases into the Murray and Murrumbidgee rivers from the Scheme's generating plant, once it came under operation. These questions expressed anxiety about changes to flood and river flow from the Scheme. Residents also sought reassurance as they scrutinised the SMA. They asked, for example, about the timing of dam releases, the amount of water that would be diverted from other rivers, whether gauges would be installed to monitor how river flow was affected by dam releases, where these gauges would be located, and, perhaps most tellingly, could the Snowy Mountains Hydro-Electric Commission (SMC), the working branch of the SMA, 'accurately assess the flow of these rivers, and ... calculate the effect which discharge of water from their generating plant will have upon the flow of these rivers, especially at times when these rivers are at their peak flow'? (Byrnes to Menzies, 9 November 1956, in 'Flood Control' pt. 1). This last question is significant as it sought to examine the river knowledge of the SMC. The floods had not only cast doubt over the abilities of engineers to control the river but also over their knowledge of the river. Did the Commission know enough about the interrelationship of the rivers, dams, floods and floodplains? Further, in asking how the SMC intended to monitor changes in river and flood flow, for example through river gauges, residents were also questioning the Commission's research and operational priorities. Not only were residents asking whether SMC and SMA decision-makers knew if floods might be increased in some places, but did they care?

As the 1956 floods occurred the river was undergoing major transformations. The previous year the first of sixteen dams that were eventually built for the Snowy Scheme was completed (Guthega Dam) and many others were under construction, including the massive Eucumbene Dam, the largest in the Snowy Scheme, which was finished two years later. However, the concerns over regulation in 1956 focused on problems of the future - what would happen to the river on completion of the Snowy Scheme - rather than in any way connecting regulation directly to the floods of that year. The floods triggered concerns about the future effects of the Scheme and also about human ability to create a stable, controllable river. The floods represented an uncontrolled danger, something that had not been foreseen, and also triggered wider doubts about what else had not been taken into account in the Scheme's planning and construction.

The Prime Minister's Office forwarded Byrnes' letter to Spooner and the Department of National Development for a response. Similar concerns had 
recently been expressed by other residents and a summary of the SMA's position had been compiled by its Commissioner, Sir William Hudson. ${ }^{13}$ Now, the Department addressed residents en masse through the press.

In the final month of 1956 Spooner issued a press statement assuring concerned residents in the Murray Valley that Snowy Scheme water releases would not aggravate 'severe' floods (Press Statement, 26 December 1956, in 'Flood Control' pt. 2). Spooner's press statement, which called on the expertise of Hudson, stated that the Commissioner had had 'this matter thoroughly investigated'. Hudson and the SMA further defended the Scheme, arguing that once completed it would in fact 'have a marked effect in reducing flooding in the Murray and Murrumbidgee' rivers via a system of reservoirs on the upper Tumut and upper Murrumbidgee rivers and water diversion tunnels. Spooner also drew attention to plans to enlarge the RMC-operated Hume Dam by a further 500,000 acre feet (half the cost being paid by the SMA), which, together with current enlargement works, would provide flood mitigation as well as more irrigation water storage (Press Statement, 26 December 1956, in 'Flood Control' pt. 2; Merritt 62). ${ }^{14}$

This press statement was picked up by a number of regional and metropolitan newspapers, including the Border Morning Mail (Albury), Advertiser (Adelaide), Mercury (Hobart), Ballarat Courier and Argus (Melbourne) ('Flood Control' pt. 2). The headline of an editorial in the Border Morning Mail read: 'Snowy Surplus No Danger to Murray River'. The article, printed on 31 December 1956, put the issue within the context of the floods of that year:

With vivid memories of the all-time record flooding of the Murray in the year ending today and the tremendous damage to valuable properties that followed and continued for several weeks, it was only natural for those in that famous old stream's lower regions to ponder upon a greater menace when the waters of the Snowy were ultimately diverted to the Murray and its Murrumbidgee tributary. ('Flood Control' pt. 2)

Residents, claimed the article, while 'as proud of the immense Snowy River project as they were when the giant Murray was harnessed in 1936' (when operation of the Hume Dam commenced), had some reservations about engineering and its consequences for the river and floods, and ultimately their lives and livelihoods. Spooner had put minds at rest, according to the Border Morning Mail: 'Fortunately for all concerned their qualms no longer exist' ('Flood Control' pt. 2).

13 Concerns had been expressed by September 1956 (see W.H. Spooner to Secretary [H.G. Raggatt], 17 September 1956, 'Flood Control' pt. 1; 'The Effect of the Construction of the Snowy Scheme on Flooding in the Snowy, Murrumbidgee and Murray Rivers' and 'The Effect of the Diversion of the Snowy River on the Flow of the Upper Murray River', statements by William Hudson, 3 September 1956, 'Flood Control' pt. 1) 14 These works on the Hume Dam supplemented another enlargement of the dam that was already increasing it to two million acre feet. An acre foot is a unit of volume, i.e. acre $=$ area, feet $=$ depth. 
Spooner's and Hudson's quick response to farmers' concerns must be seen in the context of the national and international status of the Snowy Mountains Scheme. The reputation of the Scheme as a technological achievement and national benefit was actively cultivated by its publicity branch and its leaders, including Hudson (Seddon 25-26). Merritt, in his study of the changing political and environmental contexts of grazing in the Snowy Mountains in this period, has drawn attention to the efforts of Hudson to maintain popular support for the project, as it was only through sustained public enthusiasm that the Scheme could maintain its status, avoid controversy, and, indeed, continue. For example, Merritt noted that in order to avoid negative publicity over environmental degradation during construction of the Scheme, especially soil erosion, Hudson had included a soil conservation section in the SMA's scientific division. Hudson foresaw the potential for significant political fallout as irrigators could potentially join with recreational, scientific, and other lobby groups over the issue and 'embarrass Hudson'. 'But', Merritt wrote, 'no experienced hydroelectricity engineer would willingly allow such a [public relations] disaster to happen' (60). Perhaps this was also the case with Hudson's and Spooner's speedy reply to farmers that the Scheme would not increase floods.

\section{Challenging control: the 1958 floods}

Anxieties over the effects of the Snowy Mountains Scheme on flood heights that had surfaced in 1956, which may not have been completely eased, resurfaced in 1957. The Victorian Premier, Henry Bolte, raised the issue in a letter to Acting Prime Minister Arthur Fadden in May 1957 (Bolte to Acting Prime Minister, 28 May 1957, in 'Flood Control' pt. 2). Prompted by '[r]epeated representations ... by landowners along the Upper Murray', who feared increased flooding as a result of the Snowy Mountains Scheme, the Premier put forward the concerns of a recent deputation and added some of his own. Those at the deputation, Bolte wrote, 'even now' experienced damaging inundations in the snowmelt months of late winter and spring which, he implied, were exacerbated by the yearround increased flows in the river, in turn due to Snowy Mountains Scheme diversions. The river, already carrying additional water because of the Scheme, flooded to a greater height.

While 'present flooding had its problems', Bolte wrote, 'the prospect of additional water flows', as more dams began operation, 'could be a matter of most serious concern, particularly to smaller land holders who envisaged the whole of their properties being rendered unproductive' (Bolte to Acting Prime Minister, 28 May 1957, in 'Flood Control' pt. 2). For Bolte, the SMA was clearly liable. However, in referring to the conditions of the Snowy Mountains Agreement of 1949, he was troubled that while the SMA was required to provide against soil erosion and siltation that occurred because of its regulation, it did 
not include any 'specific reference to flooding'. Bolte was further concerned that farmers and others in vulnerable areas along the Murray were not legally protected because the Snowy Mountains Agreement of 1949 authorised the diversion which caused the flooding. ${ }^{15}$ In view of the legal situation, where the SMA was under no obligation to prevent flooding caused by engineering, Bolte requested the Acting Prime Minister to extract an 'assurance' from the SMA that it would 'do all that it can to avoid damage being caused ... and that, where it is not possible for damage to be avoided, take action to compensate appropriately those persons who may suffer injury as a result of the Authority's actions' (Bolte to Acting Prime Minister, 28 May 1957, in 'Flood Control' pt. 2). Whether floods were increased by regulation was a continual source of anxiety for residents along the Murray River, particularly with the completion of the largest regulator on the Murray system, the Snowy Mountains Scheme, on the horizon.

After further floods along the Murray in 1958, residents became more outspoken on the subject, bypassing government representatives and going straight to the press. This time, though, farmers criticised the Hume Dam as well as the Snowy Mountains Scheme. In September and October 1958 the Border Morning Mail published a series of articles written by Harrison, by people in its readership sphere of the upper Murray, and by newspaper staff ('Flood Control' pt. 2). Following the newspaper's report on a 'flood protest meeting' held at Albury on 26 August, prompted by the Murray again breaking its banks, Harrison wrote a letter, published in early September and quoted at the beginning of this paper, defending the RMC's operation of the Hume Dam. Harrison denied that water releases exacerbated the flood for those below the dam, declaring that, it was not 'a "man-made" flood ... as no stored water was released' ('Flood Control' pt. 2). Border Morning Mail reporters and those who had experienced the floods saw things differently.

On the day following publication of extracts from Harrison's letter, an editorial rehashed the opinions of 'primary producers' who had held the protest meeting. The report detailed their calls for an inquiry into the role of Hume Dam releases in causing or increasing the flood, because of concerns that too much water was released by 'mistake or miscalculation'. The editorial backed the protesters' views, adding that when the Snowy Mountains Scheme was completed floods could be further 'aggravated' ('Flood Control' pt. 2).

Accusations that the RMC's operation of the Hume Dam increased flood heights along the upper Murray kept coming. In early October an article written by Albury resident V. A. Krueger, printed in the Border Morning Mail, blamed the RMC's policies as the primary source of increased flood heights ('Flood Control' 
pt. 2). Krueger argued that the RMC's policy was to fill the dam to capacity well before the irrigation season in September, refusing to leave it empty to catch floodwater - and thereby possibly reduce flood heights - because of its commitment to irrigators. It was, Krueger described, a 'no risk' policy: the RMC would not risk having an empty dam at the start of the watering season. The Albury resident labelled the policy 'weak and defeatist' arguing that those who were not irrigators suffered as a result: 'filling the weir at the earliest[,] no risk is taken with [water] conservation while every risk of flood devastation now falls on the downstream landholders - a full weir will not hold its flood waters' ('Flood Control' pt. 2). By maintaining a full dam the RMC was responsible for the flood by neglecting mitigation.

The Snowy Mountains Scheme also made an appearance in Krueger's account. The Scheme would be used to divert Snowy River water into the Hume Dam in dry years, to supply irrigation along the Murray. If a flood was then to occur, Krueger speculated, the additional water in the Hume weir would cause the peak to be higher than it would have been if the dam had remained without the diverted water. Krueger claimed that: 'Feeding these volumes of water into the [Hume] weir could, under this stringent conservation policy, later become the basis for intensified flooding' ('Flood Control' pt. 2). River regulation, which privileged irrigation, stirred emotional responses from this non-irrigator, who blamed the structures and the RMC for being impartial to his situation and that of fellow floodplain dwellers to the point that engineers would (possibly) risk exacerbating flooding for the sake of irrigation. Krueger stated that:

These water schemes have involved the nation in considerable expenditure, and in return the people are entitled to anticipate every possible benefit. But under the prevailing River Murray Commission policy one section of people [irrigators] receives benefits while other people who could be benefited [others on floodplains] are not even considered. ('Flood Control' pt. 2)

Governments were increasingly trying to manipulate an entire river system predominantly to sustain a single industry. Those who were thrown into the shadows of these polices were speaking out. The floods in 1958 affected the dairying regions of Albury more severely than the irrigation districts on the Murray, and this also possibly contributed to the outcry by non-irrigators. Here we see the beginnings of some familiar debates in the second half of the century between graziers and irrigators and between advocates of wild and regulated rivers.

The state and Commonwealth governments' bias towards irrigation created animosity from other non-irrigators, who expressed their sense of injustice at having to suffer floods for the sake of irrigation and full dams. A. Reuss, 
president of the Albury-Wodonga Milk Producers Association, spoke out on behalf of dairy farmers in the Border Morning Mail ('Flood Control' pt. 2). He blamed the Hume Dam for more frequent and larger floods that had limited milk production and ruined fodder crops. Reuss argued that floods were increased because the dam was 'kept full all the time' so that heavy rainfalls more easily turned into floods. Changes in flood rates and heights had undermined his farm knowledge and planning. The newspaper reported changes Reuss had observed. Reuss 'took over his property late in 1931 and up to 1946 there was only one flood, in 1939, and he "never had to shift a beast". The years from '41 to ' 45 yielded below-average rainfall. But between ' 46 and this year, he had been forced to move his entire herd three times'. Reuss clearly felt that dams had radically altered flood frequency and flow across his farm. One of his concerns was the damage caused by the floods, another was the uncertainty over the changing behaviour of floods. He told the newspaper, '[w]e just don't know what to expect and the authorities can't tell us'.

Reuss had little faith in 'the authorities'. He was quoted as saying: 'They are completely destroying us and we don't know how long we can stand it from a financial point of view ... you can see what the weir has done' ('Flood Control' pt. 2). The RMC was specifically targeted, as he claimed 'the RMC is not helping us at all. The man below the weir is not being considered'. He told the newspaper that the situation was so critical that he and others were organising a deputation to Spooner.

Reuss' belief that the Hume Dam could actually be used to mitigate floods added to his sense of injustice. He argued that if the RMC 'gave us a full river' as soon as the dam reached capacity, the peak height of a flood could be reduced as the water would be released steadily and the dam could hold back more of the incoming water. Like Krueger, Reuss was arguing that dams, built for irrigation, should be used to serve the interests of non-irrigators. This was a political argument. In this context, arguments for dams to be used for flood mitigation drew attention to the narrow development focus of governments towards irrigation and challenged governments to broaden the use of dams to benefit a variety of people.

The newspaper article that discussed Reuss' views was, like the others explored here, a clipping in the files of the Minister for National Development. Next to this clipping the Minister's Secretary and head of the department, Henry George Raggatt, wrote a note that outlined the difficult position of the RMC in using the Hume Dam for flood mitigation: 
The RMC had a special meeting about this. They 'can't win'. If they keep the dam full \& it rains they get this kind of complaint. If they don't keep it full \& it doesn't rain then all the irrigation cockies [small-scale farmers] will say what B.F's [sic] they are. ${ }^{16}$

The dam had been built for irrigation and seemed only able to be used for either industry water supply or flood mitigation, polarising the interests of irrigators and non-irrigators.

\section{A changing physical and cultural landscape}

Brown has argued that the 1950s witnessed greater government centralisation, partly as a by-product of the previous decades' mobilisation for war and need for increased national organisation (9). Projects of 'national development' provided a new focus for bureaucracies, such as the RMC, and the saw creation of new administrative units, like the SMA and the Department of National Development, that were the avenues for centralised government and aimed towards government projects.

That Reuss and Krueger blamed 'the authorities' is significant. Greater government involvement in river flow through these centralised organisations and dam construction and operation had made them responsible for the river in many people's eyes. Dam construction had altered the river and changed what were previously seen as natural systems. As a result floods were no longer natural disasters in the way they had been and were instead seen to come from a river controlled by officials.

In the aftermath of the 1956 floods on the Murray River, less blame was directed at the RMC, SMA and Hume Dam than two years later. The main source of anxiety for farmers was the future effects of diversions and consequent increased flooding from the Snowy Mountains Scheme, rather than the influence of dams on the current flood, even though the Hume Dam had already been operational for two decades. However, the 1956 floods witnessed the beginnings of major concerns over the effects of dams on floods, which brought together wider anxieties and a sense of injustice around dams. The debates that took place in the pages of the Border Morning Mail in 1958 show that those tensions between residents of the upper Murray and governments had not disappeared but had in fact grown, with people connecting existing regulatory structures to the floods they were experiencing. Perhaps continued flooding had made pressing concerns more urgent, and farmers, with stretched finances, more demanding. Perhaps, too, the era of technological optimism was drawing to a close.

16 'B.F.' was a common acronym for 'Bloody Fool'. 
Technically, the Hume Dam did not increase the 1956 or 1958 floods. The RMC was, however, as Krueger and Reuss argued, implicated in its failure to mitigate the floods, especially in 1958. The Hume Dam became benign in large floods, such as 1956, and tended to slightly reduce the peaks of minor floods, as in 1958. Indeed, the Hume Dam was so successful in reducing floods, later research showed that it had helped to prevent a number of floods occurring both before and after its enlargement in the late 1950s, for example in 1937, 1941, 1959, 1962, 1963, 1965 and 1968 (Sinclair 70). While this may be seen as a benefit in terms of flood mitigation, steadier river flows and the accumulation of longer periods with fewer floods has caused ramifying ecological disaster along the river and floodplains (Sinclair 70; Weir 26-29).

The construction of the Hume Dam, designed as a remedy to droughts, had coincided with a series of wet years and this may explain the causation assigned to the dam by some farmers in 1958. Their sense of injustice towards the operation of this dam was felt rather than vindicated. Perhaps non-irrigators' accusations were influenced by a broader sense of injustice, as many grazing licences in the Snowy River area had been suspended in 1958 to stem catchment erosion as the Snowy Mountains Scheme continued construction and lobby groups reacted to the environmental impact of the work (Merritt 90-92). The dams may have also become the focus of a sense of loss, symbols of changing government interests and a transforming landscape. That people were able to blame dams for floods, however, marks a shift in understandings of floods, rivers and dams. With dams and other forms of river regulation, governments became intertwined with river flow: they were, in a very real sense, embedded in the river. The distinction between natural and unnatural river flow became increasingly blurred.

\section{Conclusion}

The 1956 floods set a new agenda for engineers. In the following decades the eastern states embarked on extensive programs of dam building: to feed irrigation networks, encourage new ones, supply enough water to growing populations and industries, and in some areas to mitigate floods. The concerns of residents in Albury over changed flood flows were felt across the nation as the environmental changes caused by dams, irrigation industries' privileged position, and the challenges of limited water resources all helped to turn dams from revered national icons to controversial constructions responsible for social injustice and environmental degradation. ${ }^{17}$

The 1956 and 1958 floods prompted a decisive shift in popular thinking about responsibility for floods; thereafter governments were assumed to be responsible

17 See Powell, Watering 246-47, Figure 61 'Simplified chronology and cumulative storage capacity, Victorian water supplies' 252; Lloyd 281-89; Hallows and Thompson 41-57. 
for the wayward behaviour of rivers. The floods brought forth anxieties about environmental change and revealed a deep sense of injustice by non-irrigators towards governments' pro-irrigation policies and radical changes to the river for this industry. The floods were deeply entangled in the transformation of the Murray, both inducing and reflecting changes. The 1950s have a reputation as years of 'dullness' and conservatism, and yet here we have a major environmental event that was a turning point and which had serious long-term political effects. The 1950s was indeed a decade of change that separated an old and a new Australia. It is out of these histories of dramatic as well as subtle change, much of the complexity of which remains hidden, that we will need to create liveable water futures.

Dr Emily O'Gorman is an Associate Research Fellow at the Australian Centre for Cultural Environmental Research, University of Wollongong and a member of the Ecological Humanities group. Her research centres on changing approaches to floods, water use and food production in the Murray and Darling river systems.

\section{Acknowledgements}

This paper is based on a section of my $\mathrm{PhD}$ thesis, completed in the History Program, Research School of Social Sciences at the Australian National University in 2009. I would like to thank my PhD supervisor Tom Griffiths as well as Libby Robin, Nicholas Brown and Joe Powell whose comments and suggestions on this work in that form were extremely helpful, and whose insights have fed into this paper. I am also grateful to the two anonymous referees for their comments, which greatly improved this paper.

\section{Works Cited}

Australian Bureau of Statistics. 'Water and the Murray-Darling Basin-A Statistical Profile, 2000-01 to 2005-06 (4610.0.55.007).' Australian Bureau of Statistics, 2008. <http://www.abs.gov.au/ausstats/abs@.nsf/Latestproducts/ DC0DC8AAE4ECD727CA2574A5001F803A?opendocument $>$ Accessed 3 Jul. 2009.

Australian Bureau of Statistics. 'The Snowy Mountains Hydro-Electric Scheme.' Australian Bureau of Statistics, 2009. <http://www.abs.gov.au/ausstats/ ABS@.nsf/94713ad445ff1425ca25682000192af2/fde81ae268c76207ca2569de 00274c14!OpenDocument> Accessed 8 Jan. 2010. 
Bond, H.G., and C.J. Wiesner. 'The Floods of February 1955 in New South Wales.' Australian Meteorological Magazine. 10 Sep. 1955: 1-33.

Brown, Nicholas. Governing Prosperity: Social Change and Social Analysis in Australia in the 1950s. Cambridge: CUP, 1995.

Brunt, A.T. 'The Record Floods in Southeast Queensland, January 1956.' Australian Meteorological Magazine. 15 Dec. 1956: 12-30.

Bureau of Meteorology. 'Queensland Flood History', 'Queensland Flood Summary 1950-1959.' Bureau of Meteorology, n.d. <http://www.bom.gov. au/hydro/flood/qld/fld_history/floodsum_1950.shtml $>$ Accessed 18 Jan. 2007.

Casey, Right Honourable Lord [Richard Gavin Gardiner]. 'Preface.' In Lionel Wigmore, Struggle for the Snowy: The Background of the Snowy Mountains Scheme. London: Oxford UP, 1968: v-vi.

Chandler, Mary. '56 Memories Flood Red Cliffs. Mildura: Sunnyland Press, 1996.

Connell, Daniel. Water Politics in the Murray-Darling Basin. Leichhardt, New South Wales: Federation Press, 2007.

Costar, B.J. 'Byrnes, Sir Thomas Percy Francis (1893-1973)'. Australian Dictionary of Biography Online, 1993. <http://www.adb.online.anu.edu.au/ biogs/A130372b.htm?hilite=Byrnes $>$ Accessed 10 Oct. 2008.

Department of National Development. 'Agency Notes for agency CA 56.' National Archives of Australia, n.d. <http://naa12.naa.gov.au/scripts/AgencyDetail. asp? $\mathrm{M}=3 \& \mathrm{~B}=\mathrm{CA}+56>$ Accessed 2 Apr. 2009.

Eaton, J.H.O. A Short History of the River Murray Works. Adelaide: River Murray Commission, 1947.

Emergency Management Australia. 'EMA Disasters Database: 1956 Floods.' Emergency Management Australia, 2007. <http://www.ema.gov.au/ema/ emadisasters.nsf/c85916e930b93d50ca256d050020cblf/0fc5da61368c5094 ca256d3300057e35? OpenDocument\&Highlight $=0,1956>$ Accessed 6 Jun. 2008 .

'Flood Control-investigation of flood control and mitigation in the Murray Valley.' Item E1077 PART 1. Series A987. National Archives of Australia.

'Flood Control-investigation of flood control and mitigation in the Murray Valley.' Item E1077 PART 2. Series A987. National Archives of Australia. 
Hallows, P.J., and D.G. Thompson. The History of Irrigation in Australia. Mildura: Australian National Committee on Irrigation and Drainage, 1995.

Harrison, G.L. 'Report on the River Murray Flood Problem (with particular reference to the 1956 flood).' River Murray Commission, 1957.

Hudson, Sir William. 'Foreword.' In Lionel Wigmore, Struggle for the Snowy: The Background of the Snowy Scheme. London: Oxford UP, 1968: vii-ix.

Leslie, Jacques. Deep Water: The Epic Struggle over Dams, Displaced People and the Environment. Second edition. New York: Picador, 2006.

Leybourne, Marnie. 'Rain, Water, Governments, and a Dam: Changes to the Nomadic Pastoral System in Syria'. Water: Histories, Cultures, Ecologies. Ed. Marnie Leybourne and Andrea Gaynor. Crawley: U of Western Australia P, 2006. 28-37.

Lloyd, C.J. Either Drought or Plenty: Water Development and Management in New South Wales. Parramatta: New South Wales Department of Water Resources, 1988.

Merritt, John. Losing Ground: Grazing in the Snowy Mountains, 1944-1969. Canberra: Turalla Press, 2007.

Mitchell, Timothy. Rule of Experts: Egypt, Techno-politics, Modernity. Berkeley: U of California P, 2002.

Murray-Darling Basin Commission. Archived web page. 'River Murray Water', 'The Barrages.' Murray-Darling Basin Commission, 2006. <http://www2. mdbc.gov.au/rmw/river_murray_system/barrages.html> Accessed 12 Oct. 2009.

O'Gorman, Emily. 'Flood Country: Floods in the Murray and Darling River Systems, 1850 to the Present.' PhD thesis. Australian National University, 2009.

Pittock, Barrie, et al.. 'Climatic Background to Past and Future Floods in Australia'. Floods in an Arid Continent. Advances in Ecological Research No. 39. Ed. Aldo Poiani. Elsevier: California, 2006: 13-39.

Powell, J.M. 'Australian Water Marks: Resource-Environment Transactions in an Emergent Democracy'. Water: Histories, Cultures, Ecologies. Eds. Marnie Leybourne and Andrea Gaynor. Crawley: U of Western Australia P, 2006: 53-66.

- The Emergence of Bioregionalism in The Murray-Darling Basin. Canberra: Murray-Darling Basin Commission, 1993. 
-Watering the Garden State: Water, Land and Community in Victoria, 18341988. Sydney: Allen \& Unwin, 1989.

Reisner, Marc. Cadillac Desert: The American West and Its Disappearing Water. New York: Penguin Books, 1986.

Seddon, George. Searching for the Snowy: An Environmental History. St Leonards: Allen \& Unwin, 1994.

‘Severe Dried Fruit Losses.' Riverlander. January 1957: 29.

Sinclair, Paul. The Murray: A River and Its People. Melbourne: Melbourne UP, 2001

Snowy Mountains Hydro-electric Power Act 1949-1973.

Taylor, Philip. 'Rivers into Roads: The Terrestrialisation of a South-east Asian River Delta.' Water: Histories, Cultures, Ecologies. Ed. Marnie Leybourne and Andrea Gaynor. Crawley: U of Western Australia P, 2006. 38-52.

Tyrrell, Ian. True Gardens of the Gods: Californian-Australian Environmental Reform, 1860-1930. Berkeley: U of California P, 1999.

Weir, Jessica. Murray River Country: An Ecological Dialogue with Traditional Owners. Canberra: Aboriginal Studies Press, 2009.

Wigmore, Lionel. Struggle for the Snowy: The Background of the Snowy Mountains Scheme. London: Oxford UP, 1968.

Worster, Donald. Rivers of Empire: Water, Aridity and the Growth of the American West. Oxford: OUP, 1992.

Wright, Don, 'The River Murray: Microcosm of Australian Federal History.' Federalism in Canada and Australia: The Early Years. Ed. Bruce Hodgins et al. Canberra: Australian National UP, 1978. 277-286. 